http://dx.doi.org/10.12775/LinCop.2014.042

JOANNA KAMPER-WAREJKO

Uniwersytet Mikołaja Kopernika Instytut Języka Polskiego

\title{
Historia polskich nazw roślin występujących w poradniku P. Krescencjusza
}

Słow a kluc z e: historia języka polskiego; polszczyzna XVI wieku; historyczne fitonimy; polskie słownictwo roślinne w poradniku P. Krescencjusza

Ke y w ord s: History of the Polish language; the Polish language of the $16^{\text {th }}$ century; historical fitonyms; Polish vocabulary concerning plants in the reference manual by P. Crescentius

Słownictwo botaniczne, zarówno gwarowe, jak i ogólne, to zarejestrowane $\mathrm{w}$ drukach, ale i to $\mathrm{z}$ rękopiśmiennych zielników, było i jest w kręgu zainteresowań nie tylko botaników, historyków kultury, ale i językoznawców. (np. Budziszewska 1965; Chodurska 2003; Kamper-Warejko 2009a, 2009b, 2009c; Pawłowski 1974a, 1974b, 1975; Rogowska 1998b, 2003; Spólnik 1988, 1990, 1993; Szczaus 2002; Wajda-Adamczykowa 1989; Waniakowa 2006a, 2006b, 2006c, 2007a, 2007b; Wróbel 1962).

Szczególnie cenne pozycje powstały w ośrodku krakowskim, wśród nich jest między innymi monografia o historycznych nazwach roślin z lat 90. autorstwa Anny Spólnik (Spólnik 1990) i wydana w ubiegłym roku praca Jadwigi Waniakowej (Waniakowa 2012), dotycząca polskich gwarowych nazw dziko rosnących roślin zielnych. Gwarowymi nazwami roślin, szczególnie 
ich motywacją semantyczną, zajmowała się też Ewa Rogowska-Cybulska (Rogowska 1998a, 2005), w latach 70. również Stanisław Dubisz (Dubisz 1977). Kilka uwag problemom teoretyczno-metodologicznym poświęciła także Kwiryna Handke (Handke 1992, 1993). Na marginesie prac związanych ze słownictwem medycznym sporo uwagi poświęciła też nazwom roślin Lucyna Jankowiak (Jankowiak 2005 i 2006).

Nazwy powstałe i tworzone na polskim gruncie od pierwszych poświadczeń po wiek XIX zebrał w Słowniku polskich imion rodzajów oraz wyższych skupień roślin (1900) botanik Józef Rostafiński (Rost.S. 1900) Pomimo ponad stulecia dzielącego nas od wydania tego dzieła cały czas zadziwia ono bogactwem zebranego materiału i trudem pracy autora.

Praca A. Spólnik, zawierająca materiał historyczny (nazwy wyekscerpowane ze źródeł od XIII do XVIII wieku), podobnie jak szereg artykułów omawiających diachronicznie i etymologicznie polskie słownictwo botaniczne, nie uwzględniała nazw, które wykorzystał tłumacz polskiej wersji poradnika P. Krescencjusza. Właśnie to słownictwo, wyekscerpowane z XVI-wiecznego polskiego tłumaczenia popularnego włoskiego dzieła Piotra Krescencjusza ${ }^{1}$, jest punktem wyjścia i przedmiotem artykułu. Jest to materiał, któremu warto poświęcić uwagę. Nie uwzględniając wyrażeń, które w wyraźny sposób funkcjonują wymiennie z nazwami jednowyrazowymi oraz obcych nazw różnych rodzajów winorośli, funkcjonujących w tekście na prawach cytatów (Kamper-Warejko 2013), wynotowałam z całego zabytku ponad 400 nazw roślin. Materiał ten skonfrontowany został z istniejącą bogatą literatura przedmiotu oraz z historycznymi zasobami leksyki botanicznej (herbarzami i historycznymi słownikami). Moim celem było prześledzenie mechanizmu nominacji ${ }^{2}$ opisywanych $\mathrm{w}$ poradniku roślin i funkcjonowanie zebranych fitonimów w historycznej polszczyźnie i kolejnych stuleciach.

Jest rzeczą oczywistą, że charakter opisywanego nazewnictwa rodzi szereg trudności interpretacyjnych. Wynika to z niezwykłej różnorodności

1 Tekst Opus ruralium commodorum libri XII prawdopodobnie powstał w wieku XIII, a wydany został dopiero 150 lat po śmierci autora, w roku 1471. Korzystam z fotokopii będących w posiadaniu pracowni Słownika Polszczyzny XVI wieku w Toruniu (Cim 8145 Biblioteka Jagiellońska).

${ }^{2}$ Nominację rozumiem tu jako tworzenie pojęć w procesie nazywania i wyodrębniania fragmentów rzeczywistości, w tym wypadku nazywania otaczających człowieka roślin. Por. Encyklopedia językoznawstwa ogólnego, s. 396; Нещименко 2003; Sobotka 2006. 
nazw, tak pod względem pochodzenia, jak i funkcjonowania w nauce i świadomości użytkowników języka różnych systemów nazewniczych (Handke 1993). Źródła historyczne, do wieku XVIII, kiedy to pojawiła się klasyfikacja Linneusza, rejestrowały istniejące słownictwo ludowe i obce. Nierzadko autorzy wykorzystywali zasoby nazw istniejące już we wcześniejszych tekstach, ale też nadawali roślinom nowe nazwy, wybierając leksemy już znane lub tworząc nowe wyrazy. Takie zabiegi są źródłem istniejącej po dzień dzisiejszy dużej polisemiczności i synonimiczności tego słownictwa, zarówno w warstwie potocznej, jak i nomenklaturze naukowej. Warto tu przytoczyć, ilustrujące ten problem i znane zapewne użytkownikom języka, przykłady takich współczesnych nazw jak bez i akacja używanych potocznie i powszechnie (o powszechnym identyfikowaniu akacji z Robiniq świadczy też określenie miodu powstałego z pyłku kwiatów tego drzewa miodem akacjowym) dla nazwania odpowiednio Lilaka pospolitego i Robini biatej, przy czym obie nazwy w nomenklaturze botanicznej oznaczają inne gatunki krzewu lub drzewa - bez czarny i akację (Acacia - głównie Afryka i Australia), która w Polsce występuje sporadycznie. Dla nazwania Robinii, obok łacińskiej akacji, funkcjonuje też polska nazwa pospolita - grochodrzew (dawniej grochownik). Wyrazistym przykładem polisemii jest między innymi zarejestrowana w polskim tłumaczeniu dzieła Krescencjusza nazwa kopr. Wprowadzono ją tu kilkakrotnie. Nie biorąc pod uwagę użyć z różnymi określeniami, funkcjonuje dla nazwania Biedrzeńca anyżu (Pimpinella anisum L.) i Kopru ogrodowego (Anethum graveolens L.). Taki stan jest odzwierciedleniem wielowiekowego nawarstwiania się słownictwa botanicznego.

Analizując materiał, nie można o tych faktach zapominać. $Z$ tego też powodu punktem wyjścia były dla mnie leksemy zarejestrowane u Krescencjusza, inne nazwy tego samego desygnatu posłużyły tylko jako tło porównawcze. Zebrany materiał został oczywiście w miarę możliwości zidentyfikowany, marginalnie potraktowano jednak istotny problem przenoszenia nazw na inne rośliny. Przyporządkowanie nazw poszczególnym gatunkom roślin opisanym w zabytku ustalono na podstawie klucza do oznaczania roślin W. Szafera, S. Kulczyńskiego i B. Pawłowskiego, Rośliny polskie, książki W. Senety Dendrologia oraz prac J. Rostafińskiego ${ }^{3}$.

3 Por. Źródła na końcu pracy. 
Pierwsza polska edycja poradnika Krescencjusza ukazała się w połowie wieku XVI (1549 r.), druga - z której ekscerpowano materiał - w roku 1571. Trzeba tu wspomnieć, że oba wydania w interesującej nas warstwie językowej prawie się nie różnią. Wśród popularnych XVI-wiecznych wydań zielników sytuuje to omawiany tekst między dziełami Stefana Falimirza (1534) i Hieronima Spiczyńskiego (1542) a późniejszymi herbarzami - Marcina Siennika (1568) i Marcina z Urzędowa (1595). Opisy roślin w polskiej wersji poradnika do złudzenia przypominają opisy obecne w zielnikach. Tłumacz tekstu w interesujących nas fragmentach odszedł od łacińskiego oryginału wprowadzając w ramach poszczególnych ksiąg w miejsce układu alfabetycznego - tematyczny, wyraźnie nawiązując do - popularnych już w tym czasie - spisów roślin z podaniem ich właściwości i wskazań dotyczących ich zastosowania, nierzadko w miejsce obcych realiów wprowadzając rodzime. Księga kierowana do wszystkich zainteresowanych sztuką agrarną, hodowlą zwierząt, uprawą i zastosowaniem w życiu codziennym roślin musiała być dla odbiorcy zrozumiała i czytelna.

Wybrany z zabytku materiał zaprezentuję w ujęciu chronologicznym, z uwzględnieniem zmian, jakie przez stulecia dokonują się w nominacji roślin.

\section{Nazwy o przedpolskiej genezie}

\subsection{Fitonimy istniejące do dziś}

By przybliżyć obcy tekst odbiorcy, tłumacz, nazywając opisywane rośliny, sięgnął przede wszystkim po nazwy znane już od średniowiecza. Są w tekście fitonimy o przedpolskiej genezie ${ }^{4}$, które od najdawniejszych czasów do dziś oznaczają te same gatunki roślin. Słownictwo to znane było już w XIV i XV wieku. Do najstarszych należą nazwy zbóż, drzew i krzewów pochodzeniem sięgające indoeuropejszczyzny, niektóre w polskich źródłach rejestrowane już od wieku XIV, do takich należy cis $^{5}$ (Taxus baccata L. - Cis pospolity, por. Babik), dąb (Quercus-Dąb $<* d \varphi b z-$ Słpsł., ESSJ $^{6}$ ), owies (Avena

${ }^{4}$ Etymologię nazw roślin podaję na podstawie danych zawartych w słownikach etymologicznych i monografiach, por. Źródła.

5 Nazwy podkreślone w artykule notowane są w polszczyźnie już w XIV w.

${ }^{6}$ Poświadczenie obecności nazw w słowniku prasłowiańskim i etymologicznym słowniku języków słowiańskich jest ograniczone do haseł, które do tej pory się ukazały - Słpsł do G, ESSJ do obž-. 
L. - Owies, por. Sędzik), młodsze - znane z tekstów XV-wiecznych - to np. brzoza (łac. Betula; berza - Słpsł., ESSJ), jabłoń (Malus - Jabłoń), klon (Acer - Klon; por. ESSJ klonı, kolnъ - inne znaczenie) (por. Spól.). Tę warstwę słownictwa reprezentują też nazwy roślin posiadające między innymi właściwości lecznicze, pastewne, czy oleiste np. z rodziny motylkowatych (por. Podb.) bob (Vicia Faba L. - Bób < bobъ - Słpsł, ESSJ, por. Sędzik,) i groch (Pisum sativum L. - Groch zwyczajny, gorch - Słpsł., ESSJ, por. Sędzik), z konopiowatych chmiel (Humulus lupulus L. - Chmiel zwyczajny) i lnowatych len (Linum usitatissimum L- Len zwyczajny, por. Sędzik). Nieco młodsze, prawdopodobnie o genezie bałtosłowiańskiej, są nazwy: bez (Sambucus nigra - Dziki bez czarny; bъzъ - Słpsł., ESSJ), gruszka (Pyrus - Grusza, drzewo owocowe z podrodziny jabłkowych; por. *grusza - Słpsł., ESSJ), lipa (Tilia - Lipa <*lipa - ESSJ), wierzba (Salix alba - Wierzba) (por. Boryś, Br., Sł., Spól.). W zastaną tradycję nazewniczą wpisują się też nazwy o etymologii prasłowiańskiej, zarówno rodzime tworzone między innymi od wyglądu rośliny - kształtu, barwy - jak i miejsca występowania: brzost (łac. Ulmus glabra, rodzaj wiązu - wiąz górski, *berz- 'lśnić', nazwa od koloru drzewa Sł., Słpsł.), chebd (łac. Sambucus ebulus; rodzimy gatunek zielny bzu - Sł., por. ESSJ *xъbuzъ/ xъbъzъ/ xъbъza; *xъbъtъ/ xъbъta; xъbъtbje/ xъbъzъje), czosnek (Allium sativum L.-Czosnek pospolity; nazwa w polskich źródłach obecna już w XIII w. - Boryś, Sędzik, Sł., <* česnъ/česnb Słpsł., ESSJ), jałowiec (łac. Juniperus; od *jalovъ, bo rośnie na jałowej ziemi - Boryś, Br., Sł.; <*alovbcb/ jalovbcb ESSJ), jęczmień (Hordeum vulgare L. - Jęczmień zwyczajny - Boryś, Sędzik, Sł.), kalina (łac. Viburnum; *kalb 'błotnisty' Boryś, Sł., ESSJ - tu też * kalı/ kala/ kalo i *kalina), modrzew (łac. Larix; od koloru - Boryś), pszenica (Triticum vulgare Vill. - pszenica zwyczajna; *pbšeno 'obtłuczone ziarno' lub *pbšenz+-ica 'rozgnieciony' - Boryś, Sędzik), soczewica (Ervum lens L. - Soczewica jadalna; *sok-+-ewica-Boryś, Sędzik), sosna (łac. Pinus - Boryś); jak i prasłowiańskie zapożyczenia, m.in.: buk (łac. Fagus silvatica L. - Buk zwyczajny, z germ. - Br., Sł., por. Boryś, $<$ *bukъ Słpsł., ESSJ), cebula (Allium cepa L., z łac.cepulla przez j.niem.cibolla - Boryś, Br.), kapusta (Brassica oleracea L., z łac. compos/i/ta 'złożona, zmieszana', caputium - Boryś, Sł., por. Br.), marchew (Daucus carota L. - Marchew, ze stniem. Morha - Boryś, Br.), orkisz (Triticum spelta L. Orkisz, z tureckiego urkuš 'dziki jęczmień' - Br.), pigwa (Pyrus cydonia L., pożyczka ze Wschodu, od Persów, w czes. i rus. - tak samo - Br.), ruta (Ruta 
graveolens L., z łac. ruta - Br.), tatarka (Fagopyrum Mill. - Gryka, zboże ze Wschodu - od Tatarów ${ }^{7}$, wg K. Nitscha nazwa powstała na gruncie polskim, z niem.?, małopol.-wielkopol. tatarka, maz. gryka, poł.-wielkopol.-śląska poganka - zróżnicowane już w XVI w. - Br., por. Jank., Spól.), topola ${ }^{8}$ (Populus nigra L. - Topola czarna, z łac. populus - Boryś, Br.), wyka (Vicia sativa L. - Wyka siewna, z łac. vicia przez niem. vice - Br.).

\subsection{Nazwy zmodyfikowane w średniopolszczyźnie}

Wśród nazw dawnych odnajdujemy w poradniku też takie, które z czasem zostały zmodyfikowane lub wyszły z użycia. Do pierwszej grupy należą znane już w XV wieku wyrazy, które z czasem przybrały postać bliższą formie etymologicznej. To na przykład prasłowiańska pożyczka z łac. przez j. germ. - brzoskinia (łac. Persica vulgaris Mill., < *bersky-bve - Boryś, Br., por. Sł., $<$ *bersky Słpsł.; por. Babik), rejestrowana dla nazwania tego gatunku rośliny przez J. Rostafińskiego, znana XVI-wiecznej polszczyźnie już z zielnika Falimirza9. W tym stuleciu występuje ona obok broskinia (4x) i wariantów rozszerzonych o-w-, nawiązujących do łacińskiej pożyczki, broskwinia (6x) i brzoskwinia $(2 \mathrm{x})^{10}$; zapożyczony z łaciny hanyż (Br.) (Pimpinella anisum L.-Biedrzeniec anyż.) - forma z przydechem w XVI w. jeszcze zdecydowanie częściej używana niż anyż (48:20); inna łacińska pożyczka - izop (z łac. hyssopus, w XVw. też isop, hizop; Hissopus officinalis L. - Hyzop lekarski), w XVI wieku forma zdecydowanie dominująca (105x obok np. hizop 9x, hysop $1 \mathrm{x}$, jozop $1 \mathrm{x}) \mathrm{w}$ nomenklaturze botanicznej ustępuje miejsca hyzopowi. Odwrotny proces dobrze ilustruje obecna w poradniku nazwa Kolendry siewnej (Coriandrum sativum L.) - koriander. Forma bliska łacińskiemu pierwowzorowi, która do polszczyzny dotarła za pośrednictwem niem. (śrgniem.

${ }^{7}$ Na takie pochodzenie zboża wskazują A. Brückner (Br.) i K. Nitsch (1955, t. 2 , s. 90-91).

${ }^{8}$ U Krescencjusza pojawia się wzmianka o topoli białej (Populus alba): Drugi rodzay topoli ielt biały, bo liśćie iey ná iedney Jtronie ze Jpodku ieft białe... (456). To wcześniejsze poświadczenie niż znane dotąd z dzieła Marcina z Urzędowa (1595 r.), por. Spól., s. 75. W innych miejscach poradnika ten gatunek topoli nazywany jest jednak białodrzewinq, białodrzewiem $(455,476,487,488)$.

9 Por. Jankowiak 2006: 53. Nazwa nie odnotowana w pracy A. Spólnik. U Falimirza występująca z synonimem persykus.

10 Dane statystyczne podane za Słownikiem polszczyzny XVI wieku. 
kullander - Sł., por. Br.) i przeważała w różnych odmiankach fonetycznych w wieku XV, już w następnym stuleciu ustępuje miejsca upowszechnionej ostatecznie kolendrze. XV-wieczne zapożyczenie z języka czeskiego (Br.) trzebula (Trebula ogrodowa), występujące konsekwentnie w XVI-wiecznych zielnikach, już u J.K. Haura (Ziemiańska generalna ekonomika 1679) zastąpione zostaje upowszechnioną później formą trybula. Współwystępują w poradniku dwie formy nazwy, będącej dawną pożyczką z łacińskiego piper, gr. Piperi (Boryś, Br.). To stan znany z innych zabytków XVI-wiecznych (S. Falimirz, M. Siennik), w których obok starszej, regularnej postaci pierz (<* ppierz) pojawia się nowsza, powstała jako rezultat wyrównań w paradygmacie i znana współczesnemu użytkownikowi polszczyzny - pieprz. Innym przykładem jest zmiana obecnej już w XIV w. psł. rodzimej nazwy kopr (por. Boryś, Br.; *koprъ ESSJ). Pojawiło się tu wtórne $e$ i od wieku XVIII koper ogrodowy (Anethum graveolens) nazywamy koprem. Na marginesie nadmienię, że cytowany kopr użyty, jak i w innych tekstach z tego okresu, dla nazwania kopru ogrodowego został też przez tłumacza wykorzystany w niespotykanym dotąd kontekście. Odnajdujemy tę nazwę w opisie hanyżu: „zową ij też ináczey kminem rzym fkim álbo koprem”.

Genetycznie młodszą nazwą, która przez wieki uległa małej modyfikacji, jest pośrednia pożyczka z łac. liquiritia (Br.) dla nazwania Lukrecji gładkiej (Glycyrhiza glabra L.). Polski fitonim, znany już w XV wieku, powszechnie używany w XVI-wiecznych zielnikach to lakrycja (S. Falimirz, M. Siennik, słowniki - Murmeliusza, Mymera, Mączyńskiego), brzmieniem zbliżona do niem. Lakritze. Słownik G. Knapskiego notuje tylko tę formę, nowsza lukrecja, fonetycznie bliższa łacińskiej nazwie pojawia się obok lakrycji dopiero w wieku XVIII.

Nierzadko zmiana nazwy wynikała z wykorzystania mechanizmów słowotwórczych. Dla nazwania jednego z rodzajów wierzby obecny jest w poradniku derywat iwina, znany od $\mathrm{XV}$ wieku też z innych historycznych tekstów (np. Słownik łacińsko-polski Bartłomieja z Bydgoszczy 1532 r.) i używany $\mathrm{w}$ tym czasie synonimicznie $\mathrm{z}$ dawną prasłowiańską formą iwa (nazwa o genezie pie. - Boryś, Br., Sł.; < jiva ESSJ), która w nomenklaturze botanicznej przetrwała do dziś. Podobny komentarz odnieść można do osiczyny - derywatu od nazwy osa, o genezie pie. (por. osika - Boryś, Br.), znanej już XIV-wiecznej polszczyźnie i określającej topolę osikę. Jako przykład drobnych zmian wśród dawnych nazw zapożyczonych wymienić moż- 
na szałwiję ${ }^{11} \mathrm{z}$ łac. salvia (Br.), obecną od XV w. obok nazw szatwia, salwia; też znaną w XV wieku formę rumien., z czes. rmen, rmenek (por. rumianek - Boryś, Br.), obok której występuje w poradniku rzadka w tym czasie (w XVI w. obecna jeszcze tylko u Siennika - 1568 r.) nazwa rumnek ${ }^{12}$. Późniejszy rumianek - z wtórnym $a$ - jest albo bezpośrednim nawiązaniem do czeskiej nazwy, albo derywatem od rumien $(+-e k)$.

\subsection{Nazwy wymarle po XVI wieku}

Nazwy dawne, które z czasem wyszły z użycia reprezentowane są w poradniku na przykład przez jeden z najstarszych fitonimów - znany dla nazwania żyta już XIV-wiecznej polszczyźnie, o indoeuropejskiej genezie (Sędzik, Br.) - reż ${ }^{13}$ (Secale cereale L. - żyto zwyczajne). Tłumacz wprowadza też do tekstu, znaną staropolszczyźnie, nazwę żyto, ale tu funkcjonuje ona, najczęściej w formie pluralnej, w bardziej ogólnym znaczeniu - dla nazwania zbóż. Inna znana już w XV wieku i popularna w następnym stuleciu między innymi dla określenia rośliny z gatunku dyniowatych - nazwa bania (*ban'a 'dynia' Słpsł.), w kolejnych stuleciach (XVIII w.) ustępuje miejsca psł. dyni. Podobny los spotkał drugą nazwę tej rośliny, pojawiającą się w szeregu $b a$ nie albo korbasy (korbasy rejestruje Rost.), która jednak już w XVI-wiecznej polszczyźnie miała bardzo niską frekwencję $(3 \mathrm{x})^{14}$. Dokładnym tłumaczeniem łacińskiej nazwy petroselinum jest obecna w XV-wiecznej polszczyźnie i też jeszcze w poradniku nazwa piotruziele (przypomina czeskie nazwy tej rośliny - petrużel, petrużlen), która już w XVI stuleciu zastąpiona została przez formę piotruszka, obecną do wieku XVIII i wypieraną przez pietrusz$k e ̨$, bez przegłoszonego $e$ (Boryś, Br.). W podobnym czasie zaniknęła też nazwa $t u k$ - dawna pożyczka prasłowiańska (z jęz. germańskich, niem. lauch; w źródłach do XVII w. - por. Sędzik, Br.) - wyparta przez młodsze zapo-

11 Podobna zmiana - usunięcie joty, powszechnie występującej w łacińskich pożyczkach - zaszła z czasem w serii nazw wyekscerpowanych z zabytku. Są tu na przykład bazylija (łac. basilicum) > bazylia, lilija (łac. lilium) $>$ lilia, piwonija (łac. paeonia) $>$ piwonia.

12 Powstała przez skrócenie zapożyczonej formy rumen i dodanie przyrostka -ek.

13 Nazwa ta na określenie 'żyta' funkcjonuje dziś w polszczyźnie tylko w gwarach płd.-śląskich i kaszubskich. Por. Karłowicz, 1900-1911, t. 4, s. 23.

14 Obecna jeszcze w wieku XVII w formie kurbas oraz w innym znaczeniu w późniejszych stuleciach niespotykana. 
życzenie z łaciny - por (łac. porrum; XVI w. - Br.). W poradniku tłumacz wprowadza obie nazwy, a por można uznać za najwcześniejsze poświadczenie XVI-wieczne. Wśród nielicznych notowań z tego stulecia dla Allium porrum (9) SPXVI w. podaje jeszcze cytat z M. Siennika (1568).

\subsection{Przykłady powtórnej nominacji}

Są też w zabytku nazwy genetycznie młodsze, które wyparły staropolskie fitonimy, ale same również nie wytrzymały próby czasu. Do takich nazw należy na przykład laktuka, używana dla nazwania Sałaty siewnej. Zaczerpnięta bezpośrednio z terminologii łacińskiej (Lactuca sativa) pojawia się od XVI wieku w miejsce dawnej, prasłowiańskiej pożyczki (*loktica $<$ za pośrednictwem dial. romańskich z łac. lactuca - por. Br.) - łoczygi. Wiek XVI to okres współistnienia kilku nazw na określenie Sałaty, czego świadectwo mamy też w poradniku Krescencjusza. Obok laktuki występuje tu również satata (słowiańska pożyczka z łac. insalatum z odrzuceniem nagłosu - Br.) i to ta nazwa zwycięża ostatecznie w XVIII wieku, stając się nazwą rodzajową.

\section{Nazwy powstałe i zapożyczone na gruncie polszczyzny}

\subsection{Nazwy istniejące między XVI a XVIII w.}

Szesnasty wiek to okres, w którym ukazują się liczne edycje zielników, wzrasta zainteresowanie tematyką botaniczną, wreszcie - dzięki książkom - utrwala się dla potomnych przekazywaną od pokoleń wiedzę o roślinach. Wiele zarejestrowanych nazw znanych było już staropolszczyźnie. Są jednak i takie, których początek datuje się właśnie na wiek XVI, ale ich żywot nie przekracza wieku XVIII, nie zachowują się one w oficjalnej polskiej nomenklaturze botanicznej. Do takich nazw należy na przykład wynotowany z poradnika kolnik (z niem. kohl + przyrostek -nik, często spotykany przy nazwach roślin - Sł.; Kapusta rzepa - Brassica napus L.), znany też z późniejszego tekstu - Herbarza... M. Siennika (1568). Tłumacz poradnika na określenie tej rośliny wprowadza dodatkowo przejętą bezpośrednio z łaciny nazwę napus, również wcześniej nienotowaną i nieobecną w XVI-wiecznych zielnikach. Wydaje się, że napus nie wyszedł poza wiek XVI, kolnik - notowany jest jeszcze przez Lindego z tekstów XVIII-wiecznych, ale już w tym stuleciu zastąpiony zostaje nazwą kapusta rzepak (Kluk 1786-1788, Jundziłł 
1791). Innym przykładem mogą być nazwy topoli białej - utworzone od koloru kory drzewa - białodrzew i białodrzewina. Wcześniejsze źródła nie notują tych nazw, prawdopodobnie $\mathrm{z}$ powodu nieznajomości tego gatunku topoli ${ }^{15}$. Opracowania (Spól.) podają, że po raz pierwszy nazwa pojawia się u Marcina z Urzędowa, czyli u schyłku wieku XVI (1595 r.). Wyekscerpowany z poradnika materiał po raz kolejny ukazuje, że granicę tę można przesunąć wstecz. Topolę białą nazywa białodrzewiem jeszcze J. K. Haur (Ziemiańska generalna ekonomika, 1679), choć już w tym czasie ten gatunek drzewa nazywany jest też topola. Ta nazwa utrzymuje się do dziś. Ciekawym przykładem są też obcobrzmiące nazwy wprowadzone dla nazwania równie obcego desygnatu - owocowego drzewa granatowca. To: malogránaty álbo pomágrany i warianty tego ostatniego - pomágránaty, pomogránaty, pomográny. Wszystkie bezpośrednio nawiązujące do łacińskich nazw drzewa - malus granatum i Punica granatum. Pierwsza nazwa nie jest spotykana w zielnikach, a różnorodność form drugiej zaświadcza o jej większej popularności. Pomagranata i dwa warianty tej nazwy (pomagranatum, pomagranat) notuje już w swoim zielniku Stefan Falimirz (O ziołach i mocy ich, 1534). W późniejszych wiekach nazwy te zastąpiła zasymilowana pożyczka łacińska granatowiec.

\subsection{Nazwy istniejące do dziś}

Wśród wyrazów, które pojawiły się w polszczyźnie w wieku XV lub XVI i przetrwały do dziś wymienić można na przykład zarejestrowany w zabytku lubczyk (Lubczyk - Levisticum) - XV-wieczne zapożyczenie z jęz. germańskich (lübestecke, liebestickel, pierwotnie z łac. ligusticum - Br.). Ten wariant nazwy, w XVIw. wynotowany tylko ze Stownika J. Murmeliusza, wyparł wcześniejsze, spotykane w zielnikach - lubsczek (np. Stanko, Stefan Falimirz 1534, Szymon z Łowicza 1537, H. Spiczyński 1542), lubszczyk (Falimirz, Marcin z Urzędowa 1595, Sz. Syreniusz 1613). Forma uproszczona lubczyk - pojawia się w XVII w. w tekście J. K. Haura, później też w dziele K. Kluka. Prekursorem okazał się również tłumacz poradnika wprowadzając dla Pora, o czym była już mowa wyżej, obok dawnej nazwy - nowe zapożyczenie z łaciny - por (Br.). W średniopolskich herbarzach pojawiała się głównie wcześniejsza nazwa tuk, ług, też tuczek (G. Knapski 1621, A. Trotz 1764) i płodziszek (Sz. Syreniusz, M. Siennik). Faseol, zapożyczony w XVI w. z ła-

${ }^{15}$ SPXVIw. notuje tylko pierwszy wyraz z niską frekwencją. 
ciny (phaseolus, śrłac. fassolius, fasselus) przez śrgniem. fasol, phasol (Boryś, Br., Sł.), nie jest w tym czasie rejestrowany przez zielniki dla nazwania Fasoli. Roślinę tę nazywano grochem, bobem, w poradniku z dużym prawdopodobieństwem pod tą nazwą występuje obca roślina, zwana dziś fasola. Nazwę tę - dla Fasoli zwykłej - umieszcza w swoim dziele K. Kluk.

\subsection{Nazwy, które przetrwały w innej funkcji}

W tym miejscu warto przytoczyć też nazwy, które funkcjonują w poradniku i innych tekstach XVI-wiecznych, a z czasem stały się składową wyrażenia, drugorzędnym członem określającym roślinę. Wymienić tu można polej, XV-wieczną pożyczkę z łaciny przez j. niem. (stniem. polei < łac. pulegium - Br.), przeniesiony ze staropolszczyzny i powszechnie używany w XVI-wiecznych zielnikach dla nazwania mięty poleju (Jankowiak 2006: 384; Spól., s. 31, 89). Dopiero u Kluka i Jundziłła (XVIII w.) pojawia się Miętkiew poley i Mięta poley. Dłużej utrzymała się dla Chrysanthemum parthenium nazwa maruna, mająca też w historycznych tekstach synonimy (rzymbaba Stanko, matka wszitkich zioł, marunka Falimirz, Spiczyński, Syreniusz), pozostawiona jeszcze przez Kluka jako człon nadrzędny nazwy Maruna prawdziwa, a zdegradowana w późniejszych systematykach do członu określającego - Złocień maruna.

\section{Nazwy okazjonalne}

Są też w zabytku nazwy okazjonalne, określające na ogół jakąś odmianę lub rodzaj opisywanej rośliny. Przybliżają one obce realia botaniczne, są zapewne ściśle związane z włoskim pierwowzorem. Przykładem mogą być: Ilion jako rodzaj sałaty, Marenij jako rodzaj kasztana (maron - 'kasztan jadalny'), Melangula - rodzaj melona, Senacion - rodzaj rzeżuchy, bogaty zestaw nazw rodzajów winorośli (np. Albana, Grilla, Varana, Albamafa, Gorgániká, Pergule, Nubrolum, Mufcatella i in.). Wyrazy te, co wydaje się dość oczywiste ze względu na ich obce brzmienie, nie trafiły na podatny grunt i nie zachowały się w polszczyźnie.

Ten pobieżny przegląd nazw odnotowanych w tłumaczeniu poradnika Piotra Krescencjusza pozwala zaobserwować tendencje obecne w procesie nominacji roślin. Wyraźnie widać, że większość nazw o rodowodzie 
prasłowiańskim czy praindoeuropejskim utrwala się w języku i nie podlega zmianom w historycznej polszczyźnie. Młodsze wyrazy są często ilustracją zachodzących w historii zmian fonetycznych, nierzadko podyktowanych uproszczeniem artykulacji. Przykłady powtórnej nominacji dostarczaja dowodów z jednej strony na ciągle żywe wpływy obce (np. sałata), z drugiej wykorzystanie różnych mechanizmów słowotwórczych (np. dodawane przyrostki). Część omawianych tu nazw kontynuowana jest w naukowej nomenklaturze botanicznej, kształtującej się od XVIII wieku (dzieło K. Kluka). Dążąc do precyzji znaczeniowej i tworząc połączenia o kształcie struktur apozycyjnych, twórcy terminologii wykorzystywali istniejące od wieków wyrazy, wśród nich też nazwy tu omówione. Wynotowane przykłady ukazały również twórczy wkład tłumacza, który wykazuje się dobrą intuicją, niejednokrotnie wybierając z zasobu nazw obecnych w polszczyźnie te warianty, które przetrwały próbę czasu, do nich należy np. faseol, lubczyk, por.

\section{Źródla}

Babik - BАвік Z., 2008, Pojednanie z lasem. W stulecie „argumentu florystycznego" w slawistycznych badaniach etnogenetycznych (1908-2008), Kraków: wyd. Z. Babik.

Boryś - BoRYś W., 2008, Słownik etymologiczny języka polskiego, Kraków: Wydawnictwo Literackie.

Br. $\quad-$ BRÜCKNeR A., 1998, Stownik etymologiczny języka polskiego, Warszawa: Wiedza Powszechna.

ESSJ - Трубачов О.Н.(red.), 1974 i n., Етимологический словарь славянских языков, t. 1-31 Москва: Наука.

Jank. $\quad-\quad$ Jankowiak L. A., 2006, Stownictwo medyczne Stefana Falimirza, t. 2: Stownik, Warszawa: Instytut Slawistyki PAN.

Podb. - PodBielkowski Z., 1989, Słownik roślin użytkowych Warszawa: Państwowe Wydawnictwo Rolnicze i Leśne.

Rost.P. - Rostafiński J., 1956, Przewodnik do oznaczania roślin, Warszawa: Państwowe Wydawnictwo Rolnicze i Leśne.

Rost.S. - RostAfiński J., 1900, Symbola ad historiam naturalem medii aevi, cz.1, Kraków: Sumptibus Universitatis Cracoviae.

Seneta - Seneta W., 1987, Dendrologia, cz. 1-2, Warszawa: Państwowe Wydawnictwo Naukowe. 
Sędzik - SĘDzIK W., 1977, Prasłowiańska terminologia rolnicza. Rośliny uprawne. Użytki rolne, Wrocław: PAN Ossolineum.

Sł. $\quad-\quad$ SŁAWSKi F., 1952-1982, Słownik etymologiczny języka polskiego, t. 1-3, Kraków: nakładem TMJP.

Słpsł. - - F. Sławski (red.), 1974-2008, Słownik prasłowiański, t. 1-8, Wrocław: Ossolineum.

SPXVIw. - Mayenowa M. R., Pepłowski F. (red.), 1966-, Słownik polszczyzny XVI wieku, Wrocław: Ossolineum, Warszawa: Instytut Badań Literackich PAN (także zasoby kartoteki Słownika polszczyzny XVI w.).

Spól. - - SPólnIK A., 1990, Nazwy polskich roślin do XVIII wieku, Wrocław: Zakład Narodowy Imienia Ossolińskich, Wydawnictwo Polskiej Akademii Nauk.

Szafer - Szafer W., Kulczyński S., Pawıowski B., 1969, Rośliny polskie, Warszawa: Państwowe Wydawnictwo Naukowe.

Waniak. - WANIAKOWA J., 2012, Polskie gwarowe nazwy dziko rosnacych roślin zielnych na tle słowiańskim, Kraków: Wydawnictwo Uniwersytetu Jagiellońskiego.

\section{Bibliografia}

Budziszewska W., 1965, Stowiańskie słownictwo dotyczqce przyrody żywej, Wrocław: Zakład Narodowy Imienia Ossolińskich, Wydawnictwo Polskiej Akademii Nauk.

CHOdurska H., 2003, Ze studiów nad fitonimami rękopiśmiennych zielników wschodniosłowiańskich XVII-XVIII wieku, Kraków: Wydawnictwo Naukowe Akademii Pedagogicznej.

Dubisz S., 1977, Nazwy roślin w gwarach ostródzko-warmińsko-mazurskich, Wrocław: Zakład Narodowy Imienia Ossolińskich, Wydawnictwo Polskiej Akademii Nauk.

HANDKE K., [1992] 1997, Łacińska terminologia a polskie słownictwo botaniczne, w: K. Handke, Rozważania i analizy językoznawcze, Warszawa: Instytut Slawistyki PAN, s. 165-172.

HandKe K., [1993] 1997, Polskie nazewnictwo botaniczne oczami językoznawcy, w: K. Handke, Rozważania $i$ analizy językoznawcze, Warszawa: Instytut Slawistyki PAN, s. 173-185.

Jankowiak L. A., 2005, Stownictwo medyczne Stefana Falimirza, t. 1: Poczatki polskiej renesansowej terminologii medycznej, Warszawa: Instytut Slawistyki PAN.

JANKowiaK L. A., 2006, Słownictwo medyczne Stefana Falimirza, t. 2: Słownik, Warszawa: Instytut Slawistyki PAN. 
KAMPER-WAREJKo J., 2009a, Kilka uwag o historii nazw ziół z poradnika P. Krescencjusza (1571r.), Studia Językoznawcze 8, Szczecin, s. 71-81.

KAMPER-WarejKo J., 2009b, Nazwy roślin „z náśienia śię rodzących ná ogrodźiech ku żywnośći ludzkiey" u Krescencjusza a wybrane XVI-wieczne zielniki, Białostockie Archiwum Językowe 9, Białystok, s. 115-126.

KAMPER-WAREJKo J., 2009c, XVI-wieczne nazwy polskich roślin jako świadectwo rozwoju języka. Na podstawie „Ksiąg o gospodarstwie” Piotra Krescencjusza, w: D. Bieńkowska, A. Lenartowicz (red.), Tajemnice rozwoju, Łódź: Archidiecezjalne Wydawnictwo Łódzkie, s. 223-234.

Kamper-Warejko J., 2013, Obce nazwy winorośli występujące w poradniku P. Krescencjusza (1571), Studia Językoznawcze 12, Szczecin, s. 73-81.

KarŁowicz J., 1900-1911, Słownik gwar polskich, Kraków: Nakładem Akademii Umiejętności.

Nitsch K., 1955, Mazowieckie nazwy przyrodnicze, w tegoż: Wybór pism polonistycznych, t. 2, Kraków-Wrocław: Zakład Narodowy Imienia Ossolińskich.

PAwŁowski E., 1974a, Polskie nazwy roślin (Próba klasyfikacji semantycznej), Studia Indoeuropejskie, s. 163-169.

PAwŁowski E., 1974b, Z badań nad nazwami roślin polskich: dzięcielina, Prace Filologiczne XXV, Warszawa, s. 317-324.

PAwŁowski E., 1975, Z badań nad nazwami roślin polskich. Przenęt (Prenanthes), Język Polski LV, s. 201-205.

Polański K. (red.), 2003, Encyklopedia językoznawstwa ogólnego, Wrocław: Zakład Narodowy im. Ossolińskich.

Rogowska E., 1998a, Kaszubskie nazwy roślin uprawnych, Gdańsk: Wydawnictwo Uniwersytetu Gdańskiego.

Rogowska E., 1998b, Z kaszubskiego zielnika: Kąkol, Pomerania, nr 7/8, s. 76-77.

RogowsKa E., 2003, Aktywność słowotwórcza nazw roślin w polszczyźnie (w świetle słownika gniazd słowotwórczych współczesnego języka polskiego), w: A. Pstyga (red.), Wokót struktury stowa, Gdańsk: Wydawnictwo Uniwersytetu Gdańskiego, s. 51-61.

Rogowska E., 2005, Gwarowy obraz roślin w świetle aktywności nominacyjnej ich nazw, Gdańsk: Wydawnictwo Uniwersytetu Gdańskiego.

Sовотка P., 2006, Od predykacji do nominacji: próba rekonstrukcji żydowskiej wizji Boga na przykładzie Jego biblijnych i talmudycznych określeń, w: H. Karaś (red.), Czynić stowami, Warszawa: Wydział Polonistyki UW, s. 3-13.

SpóLniK A., 1988, Nazwy polskich roślin leczniczych w źródłach od XVI do XVIII w., w: W. Boryś (red.), Studia językoznawcze. Streszczenia prac doktorskich XII, Studia konfrontatywne i historia, Wrocław: Wydawnictwo PAN, s. 177-228. 
SPóLNIK A., 1990, Zapożyczenia w polskim nazewnictwie botanicznym w źródłach do XVIII wieku, w: M. Preyzner (red.), Język - Teoria - Dydaktyka, Kielce, s. 191-206 .

SPÓLNIK A., 1993, Nazwy roślinnych afrodyzjaków w staropolskich herbarzach, w: B. Kuźnicka (red.), Historia leków naturalnych, t. 4: Z historii i etymologii polskich nazw roślin leczniczych, Warszawa: Instytut Historii Nauki PAN, s. 51-59.

Szczaus A., 2002, Funkcjonowanie w polszczyźnie XVI wieku tożsamych znaczeniowo przymiotnikowych dubletów słowotwórczych (na przykładzie przymiotników od nazw roślin), w: M. Białoskórska, L. Mariak (red.), Synchroniczne i diachroniczne aspekty badań polszczyzny, t. 8, Szczecin: Wydawnictwo Naukowe Uniwersytetu Szczecińskiego, s. 159-171.

Wajda-Adamczy kowa L., 1989, Polskie nazwy drzew, Wrocław: Zakład Narodowy im. Ossolińskich.

WANiakowa J., 2006a, Antroponimia w polskich gwarowych nazwach roślin, w: K. Rymut (red.), Munuscula linguistica in honorem Alexandrae Cieślikowa, Kraków: Instytut Języka Polskiego PAN, s. 493-505.

Waniakowa J., 2006b, Bunch of Persian plants, w: A. Krasnowolska, K. Maciuszak, B. Mękarska (red.), In the Orient where the Gracious Light... Satura orientalis in honorem Andrzej Pisowicz, Kraków: Księgarnia Akademicka, s. 207-213.

WANiaKowA J., 2006c, Nazwy niezapominajki (Myosotis) w gwarach polskich jako przykład ekspansji słownictwa literackiego, w: J. Okoniowa (red.), Studia Dialektologiczne III, Kraków: Instytut Języka Polskiego PAN, s. 71-79.

Waniakowa J., 2007a, Dawne polskie ziela w gwarowej szacie, w: R. Laskowski, R. Mazurkiewicz (red.), Amoenitates vel lepores philologiae, Kraków: Instytut Języka Polskiego PAN, Lexis, s. 332-339.

WANIAKOWA J., 2007b, Pokrzyk wilcza jagoda - polskie nazwy gwarowe rośliny magicznej, w: S. Cygan (red.), W kręgu dialektów i folkloru. Prace ofiarowane Doktor Teresie Gołębiowskiej, Docent Wandzie Pomianowskiej i Docent Zofii Stamirowskiej, Kielce: Kieleckie Towarzystwo Naukowe, s. 215-223.

WróBel H., 1962, Związki staroczesko-staropolskie w terminologii botanicznej, Zeszyty Naukowe WSP w Katowicach, Prace Katedry Języka Polskiego II, s. 105-137.

НЕщименко Г., 2003, Проявление тенденции экономии в номинации славянских языков, w: I. Ohnheiser (red.), Komparacja systemów i funkcjonowanie wspótczesnych języków słowiańskich. Słowotwórstwo/Nominacja, Opole: Uniwersytet Opolski - Instytut Filologii Polskiej i Opolskie Towarzystwo Przyjaciół Nauk, s. $288-306$. 


\section{The History of Polish Names of Plants Appearing in P. Crescentius's Manual}

\section{( s u m mary)}

The material presented in the article comes from the second edition (1571) of the Polish translation of the reference manual by Peturs de Crescentius. To the extent possible, it was identified and confronted with the historical botanic vocabulary. The aim of the analysis is to trace the mechanism of naming plants described in the manual and to research how the fitonyms functioned in the historical Polish language at that time as well as in the subsequent centuries.

It has been noticed that most names of the pre-Slavic and pre-Indo-European origin fossilize and do not alter throughout the history of the Polish language. Words of younger origin frequently illustrate the phonetic changes which took place in order to simplify articulation. Examples of secondary nominalization, taken from the text, prove that, on the one hand, foreign influences are still present (e.g. satata); on the other hand, they manifest the use of word-formative mechanisms. Some of the names have disappeared, while others have survived and appear in the botanic nomenclature of the 18th century (in K. Kluk). Moreover, the material analyzed shows the creative input of the translator of the work, who evinced good intuition in choosing the terms which have stood the test of time (e.g. faseol, lubczyk, por). 